\title{
URGENSI KUALITAS PELAYANAN PERPUSTAKAAN PERGURUAN TINGGI
}

\author{
Rhoni Rodin ${ }^{1}$ \\ ${ }^{1}$ Kepala Perpustakaan Sekolah Tinggi Agama Islam Negeri (STAIN) Bengkulu \\ ${ }^{1}$ rhoni.rodin@gmail.com
}

\begin{abstract}
The quality of the library service refers to the needs of users. Therefore, a good service is a service that can meet the needs and wishes of the user. Then a good library is a library which is able to provide services to every pemustaka quickly and accurately. Now the theory that is used in this study among others: service quality, the dimension of the quality of service, the determining factors in the quality of service and supervision. The discussion is a total quality services can be influenced by several factors among others: word of "communication, personal need, good past experience, external communications to customer. The conclusion is that there are several factors that can improve the quality of the service on an institution that is the purpose of the organization, incentive system that used the system accountability and power structures. As an institution that performs the activity of the ministry and the library has an obligation to continually improve the quality of the service in order to meet the needs of users.
\end{abstract}

Keywords: Service, Quality Service, Library on University

ABSTRAK - Kualitas layanan perpustakaan mengacu kepada kebutuhan pemustaka. Oleh sebab itu, layanan yang baik adalah layanan yang dapat memenuhi kebutuhan dan harapan pemustaka. Maka perpustakaan yang baik merupakan perpustakaan yang dapat memberikan pelayanan kepada setiap pemustaka secara cepat dan tepat. Adapun teori yang digunakan dalam kajian ini antara lain: Kualitas pelayanan, dimensi kualitas pelayanan, faktor penentu kualitas pelayanan dan pengawasan. Pembahasannya adalah Kualitas total suatu jasa dapat dipengaruhi oleh beberapa faktor antara lain: word of mouth communication, personal need, past experience, external communications to customer. Kesimpulannya adalah Ada beberapa faktor yang dapat meningkatkan kualitas layanan pada sebuah lembaga yaitu tujuan organisasi, sistem insentif yang dipakai, sistem akuntabilitas dan struktur kekuasaan. Sebagai sebuah lembaga yang melakukan aktifitas pelayanan, maka perpustakaan berkewajiban untuk senantiasa meningkatkan kualitas layanannya, agar dapat memenuhi kebutuhan dari para pemustaka.

Kata kunci: Pelayanan, Kualitas Layanan, Perpustakaan Perguruan Tinggi

\section{PENDAHULUAN}

Perpustakaan perguruan tinggi merupakan perpustakaan yang bertugas sebagai suatu unit pelaksana teknis, mengemban tugas mendukung tujuan lembaga induknya, yaitu memberikan layanan kepada sivitas akademika dan masyarakat pemakai di sekitarnya, yang relevan dengan program Tri Dharma Perguruan Tinggi, yaitu pendidikan dan pengajaran, penelitian dan pengabdian kepada masyarakat.

Pada umumnya perpustakaan perguruan tinggi merupakan Unit Pelaksana Teknis (UPT) dan secara langsung berada dibawah rektorat. Kepala Perpustakaan bertanggung jawab langsung kepada Rektor. Dalam Peraturan Pemerintah No. 30/1990 tentang Pendidikan Tinggi disebutkan bahwa perpustakaan merupakan unsur penunjang Tri Dharma Perguruan Tinggi. 
Menurut Sulistyo Basuki (1994: 52), secara umum tujuan perpustakaan perguruan tinggi adalah: (1) memenuhi keperluan informasi masyarakat perguruan tinggi, lazimnya staf pengajar dan mahasiswa. Sering pula mencakup pula tenaga administrasi perguruan tinggi, (2) menyediakan bahan pustaka rujukan (referens) pada semua tingkat akademis, artinya mulai dari mahasiswa tahun pertama hingga ke mahasiswa program pascasarjana dan staf pengajar, (3) menyediakan ruangan belajar untuk pemakai perpustakaan, (4) menyediakan jasa peminjaman yang tepat guna bagi berbagai jenis pemakaian, dan (5) menyediakan jasa informasi aktif yang tidak saja terbatas pada lingkungan perguruan tinggi tetapi juga lembaga industri lokal.

Sebagai jantungnya perguruan tinggi, UPT Perpustakaan harus senantiasa meningkatkan pelayanannya terhadap seluruh sivitas akademika. Hal ini sesuai dengan Instruksi Presiden Nomor 1 Tahun 1995 tentang perbaikan dan Peningkatan Mutu Pelayan Aparatur Pemerintah kepada masyarakat, dan Keputusan Menteri Negara Pendayagunaan Aparatur Negara Nomor 81 Tahunn 1993 tentang Pedoman Tata Laksana Pelayanan Umum. Dengan beberapa peraturan ini, mau tidak mau perpustakaan harus berbenah dan melakukan berbagai terobosan agar dapat melakukan pelayanan yang berkualitas kepada pemustaka.

Kualitas layanan perpustakaan mengacu kepada kebutuhan pemustaka. Oleh sebab itu, layanan yang baik adalah layanan yang dapat memenuhi kebutuhan dan harapan pemustaka. Maka perpustakaan yang baik merupakan perpustakaan yang dapat memberikan pelayanan kepada setiap pemustaka secara cepat dan tepat. Keberhasilan penyajian fasilitas dan layanan perpustakaan dapat diukur dengan menggunakan kriteria frekuensi atau peminjaman bahan pustaka dan tingkat kepuasan pemustaka, karena itu kebutuhan dan permintaan pemustaka perlu diperhatikan oleh pihak perpustakaan.

Dalam dunia perpustakaan, kualitas pelayanan merupakan suatu hal yang sangat penting untuk diwujudkan, karena merupakan ujung tombak perpustakaan. Seperti yang disampaikan Soeatminah (1992: 129) yang mengatakan bahwa, baik dan tidaknya perpustakaan tergantung bagaimana pelayananya, sebab bagian pelayanan inilah yang berhubungan langsung dengan pengguna perpustakaan. Oleh sebab itu, kegiatan pelayanan dalam organisasi apapun termasuk di dalamnya perpustakaan, harus senantiasa memperhatikan kualitas pelayananya. Karena hal ini menjadi tolak ukur dan first image bagi sebuah organisasi. Apakah organisasi itu baik atau buruk, semuanya sangat bergantung dari pelayanannya.

\section{TINJAUAN PUSTAKA}

\section{Kualitas Pelayanan}

Pelayanan pada hakikatnya adalah serangkaian kegiatan dalam proses pemenuhan kebutuhan melalui aktifitas orang lain, oleh karena itu pelayanan merupakan proses. Sebagai proses, pelayanan berlangsung secara rutin dan berkesinambungan (Moenir, 1995: 27). Ini berarti bahwa pelayanan berlangsung tidak hanya satu kali melainkan berkali-kali, sehingga pengguna dapat merasakan perbedaan antara pelayanan 
ketika pertama datang ke perpustakaan dengan pelayanan untuk yang kedua kali dan seterusnya.

Berbeda dengan Sagimun dalam Purwanti (1997: 5) yang mengatakan bahwa pelayanan merupakan pemenuhan kebutuhan anggotanya, baik pemenuhan material maupun spiritual. Itu artinya bahwa kepuasan dari pengguna layanan adalah ketika kebutuhan para pengguna dapat dipenuhi oleh perpustakaan.

Sedangkan menurut Kotler (1998: 83) merumuskan pelayanan sebagai tindakan atau unjuk kerja yang ditawarkan oleh satu pihak ke pihak yang lain secara prinsip intangible dan tidak menyebabkan perpindahan kepemilikan apapun.

Menurut Olsen dan Wyekoff dalam Yamit (2001: 22), kualitas pelayanan merupakan suatu perbandingan antara harapan pemakai jasa dengan kualitas kinerja jasa pelayanan. Dengan kata lain bahwa faktor utama yang mempengaruhi kualitas pelayanan adalah kinerja karyawan yang hasilnya dirasakan oleh pengguna jasa. Harapan disini diartikan sebagai keinginan terhadap layanan yang diberikan oleh pihak penyedia jasa dalam hal ini perpustakaan kepada penggunanya. Sedangkan kualitas kinerja layanan merupakan kegiatan pokok yang dilakukan oleh sebuah lembaga jasa.

Berdasarkan beberapa pendapat para ahli, bahwa yang menjadi penekanan utama dalam hal pelayanan adalah bagaimana upaya untuk menerapkan pelayanan yang berkualitas kepada pengguna, sehingga pengguna merasa puas. Sehingga ketika kita tarik dalam konteks perpustakaan, artinya bagaimana caranya para pustakawan menerapkan pelayanan yang berkualitas ketika melayani para pemustaka.

\section{Dimensi Kualitas Pelayanan}

Menurut Parasuraman dalam Lupiyoadi (2001: 148), terdapat lima dimensi kualitas pelayanan sebagai berikut:

a. Tangibles atau bukti fisik, yaitu kemampuan suatu organisasi dalam menunjukkan eksistensinya kepada pihak eksternal. Penampilan dan kemampuan sarana dan prasarana fisik organisasi dan keadaan lingkungan sekitarnya adalah bukti nyata dari pelayanan yang diberikan oleh pemberi jasa. Ini meliputi fasilitas fisik (gedung), perlengkapan dan peralatan yang dipergunakan (teknologi), serta penampilan pegawainya.

b. Reliability atau keandalan, yaitu kemampuan organisasi (perusahaan) untuk memberikan pelayanan sesuai yang dijanjikan secara akurat dan terpercaya. Kinerja harus disesuaikan untuk pelanggan, seperti ketepatan waktu, pelayanan yang sama untuk semua pelanggan tanpa kesalahan, sikap simpatik.

c. Responsiveness atau ketanggapan, yaitu kemauan untuk membantu dan memberikan pelayanan yang cepat dan tepat kepada pelanggan, dengan penyampaian informasi yang jelas. Membiarkan konsumen menungu tanpa aanya suatu alasan yang jelas menyebabkan persepsi yang negatif dalam kualitas pelayanan.

d. Assurance atau jaminan dan kepastian, yaitu pengetahuan, kesopansantunan dan kemampuan pegawai untuk menumbuhkan rasa percaya para pelanggan perusahaan 
(organisasi). Dimana jaminan ini terdiri dari beberapa komponen; komunikasi, kredibilitas, keamanan, kompetensi dan sopan santun.

e. Empathy, yaitu memberikan perhatian yang tulus dan bersifat indiviual atau bersifat pribadi yang diberikan kepada para pelanggan dengan berupaya memahami keinginan konsumen. Suatu perusahaan (organisasi) diharapkan memiliki pengertian dan pengetahuan tentang pelanggan, memahami kebutuhan pelanggan secara spesifik, serta memiliki waktu pengoperasian yang nyaman bagi pelanggan.

Menurut Moenir (1995: 40), banyak kemungkinan tidak adanya layanan yang memadai karena:

a. tidak/kurang adanya kesadaran terhadap tugas atau kewajiban yang menjadi tanggung jawabnya. Akibatnya mereka bekerja dan melayani seenaknya; Sistem, prosedur dan metode kerja yang ada tidak memadai sehingga mekanisme kerja tidak berjalan sebagaimana yang diharapkan dan tidak berjalan sebagaimana mestinya;

b. pengorganisasian tugas pelayanan yang belum serasi, sehingga terjadi simpang siur penanganan tugas, tumpang tindih atau tercecernya suatu tugas tidak ada yang menangani;

c. pendapatan pegawai tidak mencukupi memenuhi kebutuhan hidupnya. Akibatnya pegawai tidak tenang dalam bekerja, berusaha mencari tambahan pendapatan dalam jam kerja; d. kemampuan pegawai yang tidak memadai untuk tugas yang dibebankan kepadanya. Akibatnya hasil pekerjaan tidak memenuhi standar yang telah ditetapkan;

e. tidak tersedianya sarana pelayanan yang memadai, yang mengakibatkan pekerjaan menjadi lamban, waktu banyak yang hilang dan penyelesaian masalah terlambat.

Dimensi-dimensi kualitas pelayanan yang telah dikemukakan, harus dilaksanakan dengan baik. Apabila tidak, hal tersebut akan menimbulkan kesenjangan antara organisasi (perusahaan) dan pelanggan karena perbedaan persepsi mereka tentang wujud pelayanan.

Menurut Lupiyoadi (2001:150) ada lima kesenjangan (gap) yang menyebabkan adanya perbedaan persepsi mengenai kualitas pelayanan adalah sebagai berikut:

a. Kesenjangan persepsi manajemen. Terjadi adanya perbedaan antara penilaian pelayanan menurut pengguna jasa dan persepsi managemen mengenai harapan pengguna jasa.

b. Kesenjangan spesifikasi kualitas. Terjadi kesenjangan antara persepsi manajemen mengenai harapan pengguna jasa dan spesifikasi kualitas jasa. Kesenjangan terjadi antara lain karena tidak memadainya komitmen manajemen terhadap kualitas jasa, persepsi mengenai ketidaklayakan, tidak memadainya standarisasi tugas dan tidak adanya penyusunan tujuan.

c. Kesenjangan penyampaian pelayanan. Terjadi kesenjangan antara spesifikasi 
kualitas jasa dan penyampaian jasa. Kesenjangan ini terutama disebabkan oleh faktor-faktor: (1) ambisius peran, yaitu sejauh mana pegawai dapat melakukan tugas sesuai dengan harapan pelanggan; (2) konflik peran, yaitu sejauh mana pegawai meyakini bahwa mereka tidak memuaskan semua pihak; (3) kesesuaian pegawai dengan tugas yang harus dikerjakannya; (4) kesesuaian teknologi yang digunakan pegawai; (5) sistem pengendalian dari atasan, yaitu tidak memadainya sistem penilaian dari sistem imbalan; (6) perceived control, yaitu sejauh mana pegawai merasakan kebebasan atau fleksibilitas untuk menentukan cara pelayanan; (7) team work, yaitu sejauh mana pegawai dan managemen merumuskan tujuan bersama di dalam memuaskan pelanggan secara bersama-sama dan terpadu.

d. Kesenjangan komunikasi. Terjadi kesenjangan anatara penyampaian jasa dan komunikasi eksternal. Kesenjangan ini terjadi karena tidak memadainya komunikasi horinzontal dan adanya kecenderungan untuk memberikan janji yang berlebihan. Dalam hal ini komunikasi eksternal telah mendistorsi harapan pelanggan.

e. Kesenjangan dalam pelayanan yang dirasakan. Terjadi perbedaan persepsi antara jasa yang dirasakan dan yang diharapkan oleh pelanggan.

\section{Faktor Penentu Kualitas Pelayanan}

Menurut Osborn dan Plastrik dalam hernon (1998:116) menyatakan bahwa kualitas pelayan suatu organisasi dipengaruhi oleh tujuan organisasi, sistem insentif yang dipakai, sistem akuntabilitas dan struktur kekuasaan.

Terdapat konsep lain yang memiliki kaitan erat dan berdampak langsung terhadap keberhasilan pendekatan kualitas pelayanan dalam menyediakan informasi adalah bahwa, tiap organisasi haruslah memperhatikan dan mendengarkan pendapat yang dikeluarkan oleh pelanggan mengenai jasanya. Seperti yang disampaikan Berry dan Parasuraman dalam Lupiyoadi (2001: 182), dalam mengembangkan kualitas pelayanan yang efektif melalui sistem informasi, ada lima petunjuk yang perlu dilakukan, yaitu:

a. Mengukur besarnya harapan pelanggan atas pelayanan. Perusahaan atau suatu organisasi harus dapat mengukur besarnya harapan yang muncul atas pelayanan yang diberikan kepada pelanggan.

b. Menentukan di mana titik berat kualitas informasi. Perusahaan atau organisasi harus mampu menetapkan titik berat kualitas informasi yang ingin dicapai. Penitikberatan kualitas informasi ada pada proses keputusan pihak manajemen yang berkaitan dengan peningkatan pelayanan yang diharapkan.

c. Mengetahui saran pelanggan. Perusahaan atau organisasi dituntut untuk dapat mendengarkan dan memahami saran pelanggan mengenai produk atau jasanya. 
Menghubungkan kinerja pelayanan dan output yang dihasilkan oleh perusahaan

d. Organisasi diharapkan mampu mengkaitkan kinerja pelayanan dengan tujuan organisasi.

e. Menjangkau seluruh pegawai. Penerapan sistem informasi dalam kualitas pelayanan harus mampu mencakup keseluruhan individu yang terkait di dalam hierarki organisasi. Sistem tersebut harus didesain sedemikian rupa agar semua pegawai yang berada dalam fungsi yang berbeda mendapatkan informasi yang sesuai.

\section{Pengawasan}

Salah satu faktor yang terkadang membuat suatu pelayanan tidak berjalan dengan baik adalah buruknya sistem pengawasan yang diterapkan. Jika pengawasan baik maka niscaya kegiatan pelayanan juga akan berjalan sesuai harapan, dan sebaliknya jika pengawan buruk, maka kegiatan pelayanan juga berjalan tidak sesuai harapan. Seringkali terjadi beberapa penyimpangan yang dilakukan oleh para pegawai dilapangan jika sistem pengawasan tidak berjalan dengan baik. Menurut Yuniardi (1984:137) terdapat beberapa hal yang memungkinkan terjadinya penyimpangan diantaranya : 1) unsur ketidaktentuan, 2) peristiwa yang tidak terduga sebelumnya, 3) Unsur kegagalan, 4)unsur kesalahan manusia. Keempat hal ini sangat memungkinkan terjadinya penyimpangan dalam kegiatan pelayanan. Oleh sebab itu, pengawasan merupakan harga mati bagi sebuah kegiatan pelayanan, agar kegiatan pelayanan dapat berjalan dengan maksimal sesua dengan harapan organisasi.
Adapun tujuan pengawasan menurut Siagian (1992:170-173) ada beberapa hal :

a) Untuk mengetahui apakah segala sesuatu berjalan dengan rencana yang digariskan

b) Untuk mengetahui kesulitan-kesulitan dan kelemahan dalam bekerja

c) Untuk mengetahui apakah segala sesuatu dilaksanakan dengan instruksi serta apaapa yang telah diinstruksikan

d) Untuk mengetahui apakah segala sesuatu berjalan dengan efesien

Untuk mengetahui jalan keluar jika ternyata dijumpai kesulitan, kelemahan dan kegagalan untuk menuju kearah perbaikan.

\section{METODE PENELITIAN}

Metode penelitian yang digunakan dalam tulisan ini adalah tinjauan literatur dari para pakar dan hasil penelitian yang pernah dilakukan oleh Jurusan Ilmu Perpustakaan UNDIP. Sedangkan jenis penelitian ini adalah penelitian kualitatif dan data yang didapat juga data kualitatif yang berasal dari sumber primer dan sekunder, yaitu hasil penelitian dan artikel-artikel dari para pakar. Pengumpulan data dilakukan dengan menggunakan dokumen, dan analisis data dilakukan secara kualitatif.

\section{HASIL PENELITIAN}

Jika pemustaka ditanya tentang kualitas layanan perpustakaan, tentunya akan muncul beberapa jawaban yang berbeda. Setiap pemustaka akan berlainan, memahami, menilai dan merasakan kualitas layanan. Tetapi terdapat beberapa hal yang sama berkaitan dengan kualitas 
layanan perpustakaan yang diharapkan. Diantara persamaan itu adalah:

1. Pemustaka mengharapkan kenyamanan dalam menggunakan seluruh layanan perpustakaan.

2.Pemustaka mengharapkan koleksi yang tersedia memenuhi kebutuhannya.

3.Pemustaka mengharapkan sikap yang ramah, bersahabat dan responsif dari petugas.

4.Pemustaka mengharapkan perpustakaan memiliki akses internet yang cepat.

Setiap pemustaka pasti mempunyai harapan tersendiri ketika mendatangi perpustakaan. Namun tingkat pengharapan dan prioritas layanan yang diharapkan antar pemustaka berlainan. Adanya kesesuaian antara harapan dan kenyataan yang diperoleh merupakan definisi sederhana dari kualitas.

Layanan yang berkualitas merupakan aset penting dalam dunia layanan perpustakaan. Layanan pemustaka memiliki konsep bahwa dengan mengerti dan memenuhi kebutuhan pemustaka, maka perpustakaan dapat meningkatkan kualitas layanannya. Perpustakaan yang memberikan layanan yang berkualitas kepada pemustaka berarti memberikan bantuan kepada pemustaka guna meningkatkan kepuasan mereka terhadap layanan yang diberikan oleh pihak perpustakaan.

Memang tidak mudah untuk mendefinisikan kualitas dengan tepat, akan tetapi kualitas dapat dirinci. Goetsh dan Davis (1994) menjelaskan bahwa kualitas merupakan suatu kondisi dinamis yang berhubungan dengan produk, jasa, manusia, proses dan lingkungan yang memenuhi atau melebihi harapan (Tjiptono, 2007, p. 51). Kemudian Kotler (1997, p.49) mendefinisikan
"Kualitas adalah keseluruhan ciri serta sifat suatu produk atau pelayanan yang berpengaruh pada kemampuannya untuk memuaskan kebutuhan yang dinyatakan atau yang tersirat".

Kualitas menurut ISO 9000 sebagaimana dikutip oleh Lupiyoadi (2006, p. 175) adalah degree to which a set of inherent characteristics fulfils requirements, derajat yang dicapai oleh karakteristik yang melekat dalam memenuhi persyaratan. Jadi kualitas yang diinterpretasikan ISO 9000 merupakan perpaduan antara sifat dan karakteristik yang menentukan sejauhmana keluaran dapat memenuhi persyaratan kebutuhan pelanggan. Pelanggan akan menilai sampai sejauh mana sifat dan karakteristik itu memenuhi kebutuhannya.

Konsep kualitas sendiri pada dasarnya bersifat relatif, yaitu bergantung dari perspektif yang digunakan untuk menetukan ciri-ciri dan spesifiknya. Juran (1992) memberikan definisi kualitas sebagai berikut "Quality as product features which meet costumer needs and freedom from deficiencies. The features of product or service play an important part in satisfying costumers' needs”. (T.E. Lim \& B.C. Niew, 1995, 8). Yang artinya kualitas didefinisikan sebagai fitur produk yang memenuhi kebutuhan pelanggan dan kebebasan dari kekurangan. Fitur dari produk atau jasa memainkan peranan penting dalam memuaskan kebutuhan pelanggan.

Selanjutnya menurut Tjiptono (2005, p.260) bahwa citra kualitas yang baik bukanlah berdasarkan sudut pandang atau persepsi pihak penyedia jasa, melainkan berdasarkan sudut pandang atau persepsi pelanggan. Oleh karena itu, dalam kaitannya dengan persepsi terhadap 
kualitas, citra dapat dipandang sebagai filter yang digunakan untuk mengevaluasi kualitas keseluruhan.

Berdasarkan pemaparan di atas, jadi inti dari kualitas layanan itu adalah bagaimana penyedia jasa memberikan layanan terbaik dan maksimal kepada pelanggan sehingga akhirnya akan menimbulkan persepsi dari pelanggan tersebut.

Kualitas total suatu jasa menurut Gronroos (1990, p. 38) terdiri atas dua komponen utama, yaitu:

1. Technical Quality, yaitu komponen yang berkaitan dengan kualitas output jasa yang diterima pelanggan.

2. Fungtional Quality, yaitu komponen yang berkaitan dengan kualitas cara penyampaian suatu jasa.

Sehubungan dengan kualitas jasa, diidentifikasikan bahwa ada dua komponen dasar dalam kualitas jasa yaitu kualitas teknis dan kualitas fungsional. Kualitas teknis merupakan elemen yang relatif mudah diukur secara objektif, baik oleh konsumen maupun oleh perusahaan sebagai penyedia jasa. Komponen ini menjadi dasar bagi konsumen dalam menilai kualitas jasa, tetapi karena adanya interaksi langsung antara konsumen dengan produsen maka kualitas fungsional seperti lingkugan atau penanganan oleh perusahaan akan sangat mempengaruhi penilaian konsumen terhadap kualitas jasa yang diterimanya.

Persepsi pelanggan mengenai kualitas jasa adalah membandingkan harapan mereka atas suatu pelayanan dengan pengalaman yang mereka dapatkan atas pelayanan tersebut. Kualitas jasa dinilai atas dua hal yaitu: 1. Kualitas proses, yaitu dari cara penyampaian pelayanan. 2. Kualitas teknik (outcome), yaitu kualitas hasil akhir pelayanan tersebut.

Selanjutnya menurut Zeithaml, Parasuraman dan Berry (1990, p. 19), faktor-faktor yang dapat mempengaruhi ekspektasi pengguna jasa terhadap suatu pelayanan atau produk yang ditawarkan adalah :

1. Word of mouth communication (cerita dari mulut ke mulut). Faktor ini sangat signifikan mempengaruhi harapan pelanggan atau pengguna terhadap suatu layanan. Hal ini disebabkan karena jika seorang pelanggan merasa puas dengan layanan yang diberikan oleh suatu pihak penyedia jasa, maka seorang pelanggan akan bercerita mengenai bagusnya pelayanan yang ia terima. Akan tetapi sebaliknya, jika pelayanan yang ia terima kurang memuaskan maka ia pun menyampaikannya kepada yang lain.

2. Personal need (kebutuhan diri). Harapan pelanggan muncul dalam hal ini karena karakteristik dan kebutuhan dalam diri mereka.

3. Past experience (pengalaman masa lalu). Faktor pengalaman sebelumnya sangat mempengaruhi pelanggan untuk menggunakan jasa atau layanan tertentu. Pengalaman ketika pernah menggunakan suatu layanan akan memberikan pelajaran kepada seorang pelanggan apakah akan menggunakan layanan tersebut lagi ataukah pindah ke jasa layanan yang lain.

\section{External communications to costumers} (komunikasi eksternal). Sebagai contoh dari komunikasi eksternal ini adalah 
tayangan iklan di media massa baik cetak maupun elektronik. Hal ini sangat berpengaruh bagi pelanggan dalam menilai kualitas suatu layanan.

Kualitas layanan perpustakaan mengacu kepada kebutuhan pemustaka. Oleh sebab itu, layanan yang baik adalah layanan yang dapat memenuhi kebutuhan dan harapan pemustaka. Maka perpustakaan yang baik merupakan perpustakaan yang dapat memberikan pelayanan kepada setiap pemustaka secara cepat dan tepat. Keberhasilan penyajian fasilitas dan layanan perpustakaan dapat diukur dengan menggunakan kriteria frekuensi atau peminjaman bahan pustaka dan tingkat kepuasan pemustaka, karena itu kebutuhan dan permintaan pemustaka perlu diperhatikan oleh pihak perpustakaan. Dalam kegiatan pelayanan memerlukan suatu sikap positif di hadapan pelanggan. Senyum, tutur kata, gerak gerik, cara berpakaian, dan kecekatan dalam melayani pelanggan akan memberikan nilai tambah yang besar bagi kepuasan pelanggan.

Berdasarkan pemaparan diatas maka dapat dipahami bahwa memberikan layanan yang terbaik bagi pelanggan terfokus pada sikap dan perhatian dari penyedia jasa. Sikap dan perhatian ini akan menjadi tolok ukur sebagai langkah awal dalam memberikan kepuasan kepada pelanggan. Oleh karena itu, meningkatkan kualitas pelayanan merupakan suatu hal yang sangat urgen bagi suatu perpustakaan, sehingga pada akhirnya para pemustaka merasa puas dengan pelayanan yang mereka terima.

\section{SIMPULAN}

Dari uraian tersebut di atas, dapat digaris bawahi bahwa:

1. Salah satu tugas perpustakaan Perguruan Tinggi adalah melakukan pelayanan kepada seluruh sivitas akademika di perguruan tinggi.

2. Sebagai sebuah lembaga yang melakukan aktifitas pelayanan, maka perpustakaan berkewajiban untuk senantiasa meningkatkan kualitas layanannya, agar dapat memenuhi kebutuhan dari para pemustaka.

3. Dimensi-dimensi kualitas pelayanan seperti, $\quad$ Tangibles, Reliability, Responsiveness, Assurance, Empathy harus dilaksanakan agar tidak menimbulkan kesenjangan antara organisasi (perusahaan) dan pelanggan karena perbedaan persepsi mereka tentang wujud pelayanan

4. Ada beberapa faktor yang dapat meningkatkan kualitas layanan pada sebuah lembaga yaitu tujuan organisasi, sistem insentif yang dipakai, sistem akuntabilitas dan struktur kekuasaan

5. Untuk mengetahui apakah kegiatan berjalan sesuai dengan harapan dari rencana organisasi, maka perlu dilaksanakan kegiatan pengawasan.

\section{DAFTAR PUSTAKA}

Basuki, Sulistyo. (1994). Pengantar Ilmu Perpustakaan. Jakarta: Gramedia Pustaka Utama.

Effendy, Onong Uchjana. (2001). Ilmu Komunikasi. Bandung: Remaja Rosdakarya. 
Gronroos, Christian. (1990). Service management and marketing : managing the moments of truth in service competition. Singapore: Maxwell Macmillan.

Hernon, Petter and Ellen Altman. (1998). Assesing Service Quality:Satisfaying the Expectations of Library Customer. Chicago:American Library Association.

Kotler, Philip \& Keller, Kevin Lane (2009). Marketing management ; thirteenth edition. New Jersey : Pearson Prentice Hall.

Lim, T.E \& Niew, B.C. (1995). Quality management system : assessment to ISO 9000:1994 series. Singapore : Prentice Hall.

Lupiyoadi, Rambat. (2001). Manajemen Pemasaran Jasa Teori dan Praktek. Jakarta: Salemba Empat.

Moenir, A. S. (1995). Manajemen Pelayanan Umum. Jakarta: Bumi Aksara.

Siagian, Sondang P. (1992). Fungsi-Fungsi Managerial. Jakarta: Bumi Aksara.

Soeatminah.

Perpustakaan, Kepustakawanan dan Pustakawan. Jogjakarta. Kanisius.

Sutarno. (2006). Perpustakaan dan Masyarakat. Edisi revisi. Jakarta: CV. Sagung Seto.

Tjiptono, Fandy. (2007). Manajemen jasa. Yogyakarta: Andi.

Yuiardi. (1984). Manajemen Pemasaran. Bandung:Remaja Rosdakarya.

Zeithaml, A. Valarie, Parasuraman, A., dan Berry, L. (1990). Delivering quality service: balancing costumer perceptions and expectations. New York: The Free Press. 